\title{
Performance Analysis of Space vector pulse width modulation based Sensor less Field oriented control of Brushless DC motor
}

\begin{abstract}
Meghana N Gujjar ${ }^{1}$, Pradeep Kumar ${ }^{2}$
PG Scholar, Electrical and Electronics Engineering, N.M.A.M Institute of Technology, Nitte, Karnataka, India ${ }^{1}$ Assistant Professor, Electrical and Electronics Engineering, N.M.A.M Institute of Technology, Nitte, Karnataka, India ${ }^{2}$

Abstract: This paper presents an approach to Field oriented control (FOC) of Brushless DC (BLDC) motor producing significantly less torque ripple. The sensorless Field oriented control of BLDC motor is more efficient in terms of torque generation compared to back emf zero crossing technique. It allows independent control of torque and rotor flux by controlling the torque and flux producing current components. The space vector pulse width modulation generates switching pulses for inverter switches aids improved system performance with reduced total harmonic distortion compared to other PWM technique. The simulation of SVPWM based sensorless indirect field oriented control of BLDC motor with necessary vector (Clark-Park) transformation is carried out using MATLAB/SIMULINK.
\end{abstract}

Keywords: Brushless DC motor, field oriented control, space vector pulse width modulation, Clark-park transformation.

\section{INTRODUCTION}

A Brushless DC motor is a permanent magnet synchronous motor which uses rotor position sensors for efficient commutation of inverter switches. It overcomes the drawback of brushed DC motor as it does not have mechanical commutator and brushes. Presently PMBLDC motors are replacing DC motors, universal motors and induction motors in low power applications since they are efficient, requires less maintenance and smaller in size. For inverter switching either sensor or sensorless techniques can be used. In some applications where the motor is enclosed like compressor sensored method is impractical hence sensorless is preferred. Presently the Parmanent magnet BLDC motor is becoming widely used in consumer, industrial and electric vehicle applications as they have advantages such as high efficiency, fast dynamic response and better speed versus torque characteristics. Also they are finding applications in variable speed control of AC motor drives.

The Indirect field oriented control technique is one of the efficient and effective motor control schemes which allow smooth torque operation. It is extensively used in high performance $\mathrm{AC}$ and $\mathrm{DC}$ motor drives [1]. It can be accomplished by decoupled control of electromagnetic torque and rotor flux using co-ordinate transformation which improves transient response of motor. The vector or FOC algorithm provides different scheme of rotor position estimation efficiently controls the motor without the use of any mechanical rotating sensor and provides better torque performance and reduced torque ripple.

\section{SYSTEM STUDY}

The block diagram of system study is shown in Fig.1. The BLDC motor load is connected to the constant DC voltage source through 3-phase voltage source inverter (VSI). Using the position encoder rotor angle and speed can be sensed and are used as feedback signals. The field oriented control scheme provides reference voltage signal to the Space vector Pulse width modulation which generates switching sequence for the inverter.

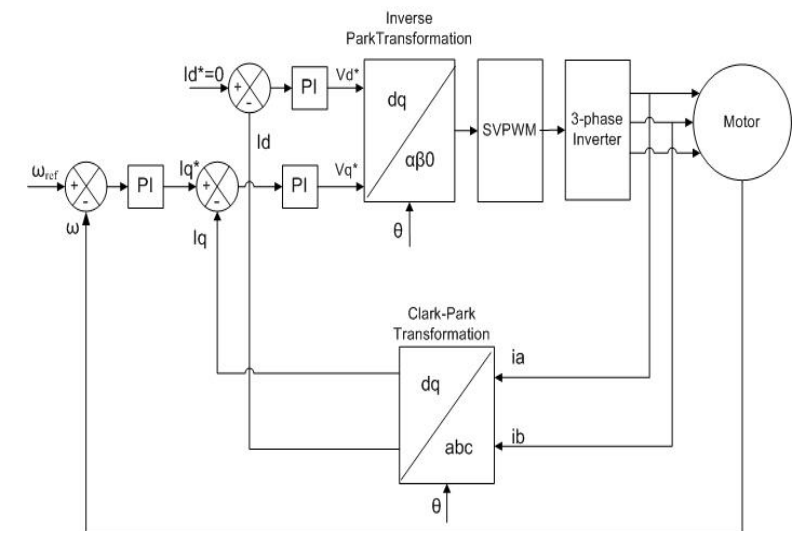

Fig. 1. Block diagram of the SVPWM based field oriented control of PMBLDC motor

\section{III.BLDC MOTOR MODELLING}

The PMBLDC motor modelled here is a 3 phase 8 pole motor. Its modelling is similar to that of synchronous 
machine. The three phase star connected BLDC motor The electromagnetic torque equation can be expressed as: equations are as follows:

$$
\begin{aligned}
& V_{a}=R_{a} i_{a}+(L-M) \frac{d i_{a}}{d t}+e_{a} \\
& V_{b}=R_{b} i_{b}+(L-M) \frac{d i_{b}}{d t}+e_{b} \\
& V_{c}=R_{c} i_{c}+(L-M) \frac{d i_{c}}{d t}+e_{c}
\end{aligned}
$$

Assuming all the phase resistances is equal in balanced three phase system,

$\mathrm{R}_{\mathrm{a}}=\mathrm{R}_{\mathrm{b}}=\mathrm{R}_{\mathrm{c}}=\mathrm{R}$

The phase voltage equation in matrix form is as below:

$$
\left[\begin{array}{l}
V a \\
V b \\
V c
\end{array}\right]=\left[\begin{array}{ccc}
R & 0 & 0 \\
0 & R & 0 \\
0 & 0 & R
\end{array}\right]\left[\begin{array}{c}
i a \\
i b \\
i c
\end{array}\right]+\left[\begin{array}{ccc}
\mathrm{L}-\mathrm{M} & 0 & 0 \\
0 & \mathrm{~L}-\mathrm{M} & 0 \\
0 & 0 & L-M
\end{array}\right] \frac{d}{d t}\left[\begin{array}{c}
i a \\
i b \\
i c
\end{array}\right]+\left[\begin{array}{c}
e a \\
e b \\
e c
\end{array}\right]
$$

(4) Step1: The control process starts by measuring the

Where, $\mathrm{Va}, \mathrm{Vb}, \mathrm{Vc}=$ terminal phase voltage $[\mathrm{V}], \mathrm{R}=$ armature resistance $[\Omega], \mathrm{L}=$ armature self inductance $[\mathrm{H}]$, $\mathrm{M}=$ mutual inductance between any two phases, $\mathrm{i}_{\mathrm{a}}, \mathrm{i}_{\mathrm{b}}, \mathrm{i}_{\mathrm{c}}=$ stator phase current $[\mathrm{A}], \mathrm{e}_{\mathrm{a}}, \mathrm{e}_{\mathrm{b}}, \mathrm{e}_{\mathrm{c}}=$ motor back emf [V]

Back emf of each phase is displaced by $120^{\circ}$ phase shift. The back emf equation for each phase is as follows:

$$
\begin{aligned}
e_{a}= & K_{w} f\left(\theta_{e}\right) \omega \\
& e_{b}=K_{w} f\left(\theta_{e}-\frac{2 \Pi}{3}\right) \omega \\
& e_{c}=K_{w} f\left(\theta_{e}+\frac{2 \Pi}{3}\right) \omega
\end{aligned}
$$

The function $\mathrm{f}(\mathrm{)}$ ) provides the trapezoidal waveform of back emf signal. For one cycle of this function, its equation can be written as:

$$
f(\theta)=\left\{\begin{array}{l}
1,\left(0 \leq \theta_{e}<\frac{2 \Pi}{3}\right) \\
1-\frac{6}{\Pi}\left(\theta_{e}-\frac{2 \Pi}{3}\right),\left(\frac{2 \Pi}{3} \leq \theta_{e}<\Pi\right) \\
-1,\left(\Pi \leq \theta_{e}<\frac{5 \Pi}{3}\right) \\
-1+\frac{6}{\Pi}\left(\theta_{e}-\frac{5 \Pi}{3}\right),\left(\frac{5 \Pi}{3} \leq \theta_{e}<2 \Pi\right)
\end{array}\right.
$$

where, $\mathrm{Kw}=$ back emf constant $[\mathrm{V} / \mathrm{rad} . \mathrm{S}-1], \theta_{\mathrm{e}}=$ rotor position in electrical degree, $\omega=$ rotor speed [rad.S-1]

Rotor mechanical and electrical angle are related as follows:

$$
\theta_{e}=\frac{P}{2} \theta_{m}
$$
armature currents. Instead of three, two of three phase

$T_{e}=J \frac{d \omega}{d t}+B \omega+T_{L}$

In BLDC motor the electromagnetic torque depends on the current, motor speed and back emf. Hence the instantaneous torque equation is given as:

$T_{\text {em }}=\frac{1}{\omega}\left(e_{a} i_{a}+e_{b} i_{b}+e_{c} i_{c}\right)$

Where, $\mathrm{P}=$ number of poles, $\mathrm{T}_{\mathrm{L}}=$ load torque $[\mathrm{NM}], \mathrm{J}=$ moment of inertia $[\mathrm{Kgm} 2], \mathrm{B}=$ friction constant [Nms.rad.s-1]

\section{IV.INDIRECT FIELD ORIENTED CONTROL SCHEME}

currents $i_{a}, i_{b}$ are sensed. The third phase current $i_{c}$ is calculated by using the relation as given below:

$i_{a}+i_{b}+i_{c}=0$

The combined vector representation of current in three reference frames is shown in Fig. 2.

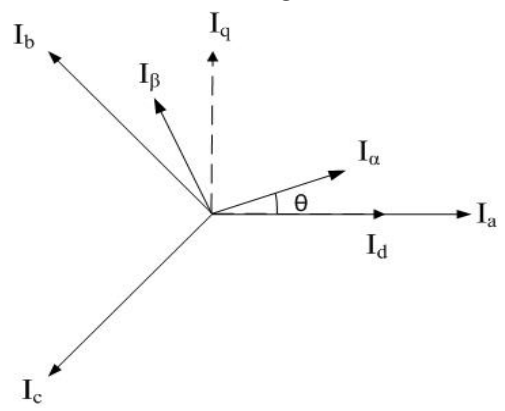

Fig. 2. Combined current vector representation

Step 2: The 3-phase stator currents are converted into the $(\alpha-\beta)$ two dimensional orthogonal system using Clark's transformation as presented below:

$$
\begin{aligned}
& i_{\alpha}=i_{a} \\
& i_{\beta}=\frac{1}{\sqrt{3}} i_{a}+\frac{2}{\sqrt{3}} i_{b}
\end{aligned}
$$

Step3: The time variant two dimensional $(\alpha, \beta)$ currents generated in step 2 are transformed to the $\mathrm{d}, \mathrm{q}$ rotational reference frame. This conversion is called as Park's transformation.

$$
\begin{gathered}
i_{d}=i_{\alpha} \cos \theta+i_{\beta} \sin \theta \\
i_{q}=-i_{\alpha} \sin \theta+i_{\beta} \cos \theta
\end{gathered}
$$

Where, $\theta$ is the rotor flux position. 
The currents $i_{d}, i_{q}$ are flux and torque controlling There are eight possible switching states $\left(V_{0}\right.$ to $\left.V_{7}\right)$ for 3 components respectively and are time invariant in nature.

Step 4: For permanent magnet machine, $i_{d}$ reference value is generally kept zero, whereas the reference value for $i_{q}$ is generated from torque command which is generated from the speed control loop. These two references are compared with actual feedback signals. The error signals generated from comparator are then processed using PI controllers. The outputs of PI controllers give the reference $\left(V_{d}, V_{q}\right)$ voltge vectors.

Step 5: Using Inverse Park's transformation the voltages in $d, q$ rotating reference frame are translated back to the $(\alpha, \beta)$ stationary orthogonal reference frame.

$V_{\alpha}=V_{d} \cos \theta-V_{q} \sin \theta$

$V_{\beta}=V_{d} \sin \theta+V_{q} \cos \theta$

The resulting voltage vectors $\mathrm{V}_{\alpha}$ and $\mathrm{V}_{\beta}$ are then used to perform Space vector pulse width modulation.

\section{SPACE VECTOR PULSE WIDTH MODULATION}

Space vector modulation is an advanced computational intensive technique used for modulating the inverter output voltage and is the best PWM technique for variable speed drive applications. It is used to generate sine wave that gives higher voltage to the motor with lower total harmonic distortion. The SVPWM technique utilizes DC bus voltage more efficiently and generates less harmonic distortion compared to other PWM methods.

Here the three phase system is represented in a vector rotating with angular velocity with respect to stationary orthogonal reference $\alpha-\beta$ axes where $\alpha$-axis coincides with $\mathrm{V}_{\mathrm{a}}$ phase voltage axis. In this modulation technique revolving reference voltage vector is taken as voltage reference. The magnitude and frequency of fundamental components in the line side are controlled by the magnitude and frequency of reference voltage vector. The vector representation of SVM is as shown in Fig. 3.

phase 2-level inverter powering from DC voltage source Vdc. The ON devices of inverter, switching states and corresponding phase and line voltages machine are summarized in Table 1.

TABLE I SUMMARY OF SWITCHING STATES, PHASE VOLTAGE AND LINE TO LINE VOLTAGE

\begin{tabular}{|c|c|c|c|c|c|c|c|c|}
\hline \multirow[t]{2}{*}{$\begin{array}{l}\text { St } \\
\text { ate }\end{array}$} & \multirow{2}{*}{$\begin{array}{l}\text { Space } \\
\text { voltage } \\
\text { vector }\end{array}$} & \multirow{2}{*}{$\begin{array}{l}\text { ON } \\
\text { devic } \\
\text { es }\end{array}$} & \multicolumn{3}{|c|}{ Phase voltage } & \multicolumn{3}{|c|}{$\begin{array}{l}\text { Line } \\
\text { voltage }\end{array}$} \\
\hline & & & $\mathrm{V}_{\mathrm{an}}$ & $\mathrm{V}_{\mathrm{bn}}$ & $\mathrm{V}_{\mathrm{cn}}$ & $\mathrm{V}$ & $\mathrm{V}$ & V \\
\hline 0 & $\begin{array}{l}\mathrm{V} 0= \\
(000)\end{array}$ & $\begin{array}{l}\text { S4 S6 } \\
\text { S2 }\end{array}$ & 0 & 0 & 0 & 0 & 0 & 0 \\
\hline 1 & $\begin{array}{l}\mathrm{V} 1= \\
(100)\end{array}$ & $\begin{array}{l}\text { S1 S6 } \\
\text { S2 }\end{array}$ & $2 / 3$ & $-1 / 3$ & $-1 / 3$ & 1 & 0 & $\overline{-}$ \\
\hline 2 & $\begin{array}{l}\text { V2= } \\
(110)\end{array}$ & $\begin{array}{l}\text { S1 S3 } \\
\text { S2 }\end{array}$ & $1 / 3$ & $1 / 3$ & $-2 / 3$ & 0 & 1 & $\begin{array}{l}- \\
1\end{array}$ \\
\hline 3 & $\begin{array}{l}\text { V3= } \\
(010)\end{array}$ & $\begin{array}{l}\text { S4 S3 } \\
\text { S2 }\end{array}$ & $\begin{array}{l}- \\
1 / 3\end{array}$ & $2 / 3$ & $-1 / 3$ & $\overline{1}$ & 1 & 0 \\
\hline 4 & $\begin{array}{l}\mathrm{V} 4= \\
(011)\end{array}$ & $\begin{array}{l}\text { S4 S3 } \\
\text { S5 }\end{array}$ & $\begin{array}{l}- \\
2 / 3\end{array}$ & $1 / 3$ & $1 / 3$ & $\overline{-}$ & 0 & 1 \\
\hline 5 & $\begin{array}{l}\text { V5= } \\
(001)\end{array}$ & $\begin{array}{l}\text { S4 S6 } \\
\text { S5 }\end{array}$ & $\begin{array}{l}- \\
1 / 3\end{array}$ & $-1 / 3$ & $2 / 3$ & 0 & 1 & 1 \\
\hline 6 & $\begin{array}{l}\text { V6= } \\
(101)\end{array}$ & $\begin{array}{l}\text { S1 S6 } \\
\text { S5 }\end{array}$ & $1 / 3$ & $-2 / 3$ & $1 / 3$ & 1 & $\begin{array}{l}- \\
1\end{array}$ & 0 \\
\hline 7 & $\begin{array}{l}\text { V7= } \\
(111)\end{array}$ & $\begin{array}{l}\text { S1 S3 } \\
\text { S5 }\end{array}$ & 0 & 0 & 0 & 0 & 0 & 0 \\
\hline
\end{tabular}

The desired 3 phase output voltage equations are described as:

$V_{a}=V_{m} \cos \omega t$

$V_{b}=V_{m} \cos \left(\omega t-120^{\circ}\right)$

$V_{c}=V_{m} \cos \left(\omega t+120^{\circ}\right)$

The reference voltage can be expressed as:

$V_{r e f}=\sqrt{\frac{3}{2}} V_{m} e^{j \theta}$

Where, $\theta=\omega \mathrm{t}=2 \pi \mathrm{ft}$

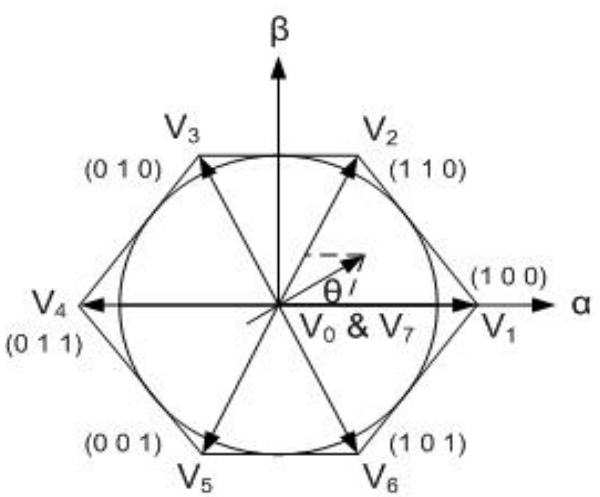

Fig. 3. SVPWM vector representation

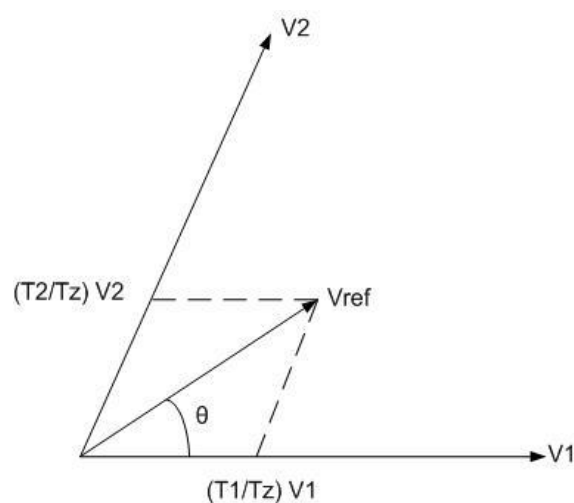

Fig. 4. Sector 1 representation 
The reference voltage is the summation of adjacent A. MATLAB/SIMULINK simulation vectors. The vector representation of sector 1 with reference voltage is as shown in Fig. 4.

$\overrightarrow{V_{\text {ref }}} T_{Z}=\overrightarrow{V_{1}} T_{1}+\overrightarrow{V_{2}} T_{2}$

$\because \phi=\theta-(N-1) 60$

Where $T z=1 / f s$, fs is switching frequency, $\Phi$ is angle between each vector within 0 to 60 degree , $\mathrm{N}=$ number of sector from 1 to 6

Switching periods T1, T2, T0 can be determined using the equations given below:

$T_{1}=T_{z} \frac{2}{\sqrt{3}} \frac{V_{r e f}}{V_{1}} \sin (60-\phi)$

$T_{2}=T_{z} \frac{2}{\sqrt{3}} \frac{V_{r e f}}{V_{2}} \sin (\phi)$

$T_{0}=T_{z}-\left(T_{1}+T_{2}\right)$

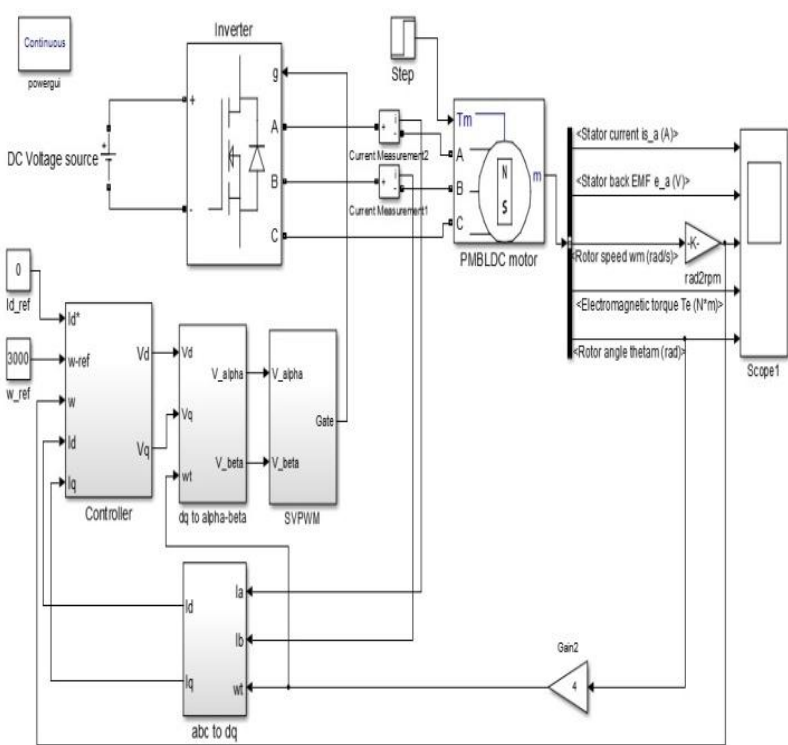

Fig. 5. Simulation block diagram of SVPWM based Field oriented control of BLDC motor

Table 2. gives the summary of switching time at each sector.

TABLE II CALCULATION OF SWITCHING TIME AT EACH INTERVAL

\begin{tabular}{|l|l|l|}
\hline Sector & \multicolumn{1}{|c|}{$\begin{array}{c}\text { Upper switches } \\
\left(\mathrm{S} 1, \mathrm{~S}_{3}, \mathrm{~S} 5\right)\end{array}$} & \multicolumn{1}{|c|}{$\begin{array}{c}\text { Lower switches } \\
\text { (S4,S6,S2) }\end{array}$} \\
\hline 1 & $\mathrm{~S}_{1}=\mathrm{T}_{1}+\mathrm{T}_{2}+\mathrm{T}_{0} / 2$ & $\mathrm{~S}_{4}=\mathrm{T}_{0} / 2$ \\
& $\mathrm{~S}_{3}=\mathrm{T}_{2}+\mathrm{T}_{0} / 2$ & $\mathrm{~S}_{6}=\mathrm{T}_{1}+\mathrm{T}_{0} / 2$ \\
& $\mathrm{~S}_{5}=\mathrm{T}_{0} / 2$ & $\mathrm{~S}_{2}=\mathrm{T}_{1}+\mathrm{T}_{2}+\mathrm{T}_{0} / 2$ \\
\hline 2 & $\mathrm{~S}_{1}=\mathrm{T}_{1}+\mathrm{T}_{0} / 2$ & $\mathrm{~S}_{4}=\mathrm{T}_{2}+\mathrm{T}_{0} / 2$ \\
& $\mathrm{~S}_{3}=\mathrm{T}_{1}+\mathrm{T}_{2}+\mathrm{T}_{0} / 2$ & $\mathrm{~S}_{6}=\mathrm{T}_{0} / 2$ \\
& $\mathrm{~S}_{5}=\mathrm{T}_{0} / 2$ & $\mathrm{~S}_{2}=\mathrm{T}_{1}+\mathrm{T}_{2}+\mathrm{T}_{0} / 2$ \\
\hline 3 & $\mathrm{~S}_{1}=\mathrm{T}_{0} / 2$ & $\mathrm{~S}_{4}=\mathrm{T}_{1}+\mathrm{T}_{2}+\mathrm{T}_{0} / 2$ \\
& $\mathrm{~S}_{3}=\mathrm{T}_{1}+\mathrm{T}_{2}+\mathrm{T}_{0} / 2$ & $\mathrm{~S}_{6}=\mathrm{T}_{0} / 2$ \\
& $\mathrm{~S}_{5}=\mathrm{T}_{2}+\mathrm{T}_{0} / 2$ & $\mathrm{~S}_{2}=\mathrm{T}_{1}+\mathrm{T}_{0} / 2$ \\
\hline 4 & $\mathrm{~S}_{1}=\mathrm{T}_{0} / 2$ & $\mathrm{~S}_{4}=\mathrm{T}_{1}+\mathrm{T}_{2}+\mathrm{T}_{0} / 2$ \\
& $\mathrm{~S}_{3}=\mathrm{T}_{1}+\mathrm{T}_{0} / 2$ & $\mathrm{~S}_{6}=\mathrm{T}_{2}+\mathrm{T}_{0} / 2$ \\
& $\mathrm{~S}_{5}=\mathrm{T}_{1}+\mathrm{T}_{2}+\mathrm{T}_{0} / 2$ & $\mathrm{~S}_{2}=\mathrm{T}_{0} / 2$ \\
\hline 5 & $\mathrm{~S}_{1}=\mathrm{T}_{2}+\mathrm{T}_{0} / 2$ & $\mathrm{~S}_{4}=\mathrm{T}_{1}+\mathrm{T}_{0} / 2$ \\
& $\mathrm{~S}_{3}=\mathrm{T}_{0} / 2$ & $\mathrm{~S}_{6}=\mathrm{T}_{1}+\mathrm{T}_{2}+\mathrm{T}_{0} / 2$ \\
& $\mathrm{~S}_{5}=\mathrm{T}_{1}+\mathrm{T}_{2}+\mathrm{T}_{0} / 2$ & $\mathrm{~S}_{2}=\mathrm{T}_{0} / 2$ \\
\hline 6 & $\mathrm{~S}_{1}=\mathrm{T}_{1}+\mathrm{T}_{2}+\mathrm{T}_{0} / 2$ & $\mathrm{~S}_{4}=\mathrm{T}_{0} / 2$ \\
& $\mathrm{~S}_{3}=\mathrm{T}_{0} / 2$ & $\mathrm{~S}_{6}=\mathrm{T}_{1}+\mathrm{T}_{2}+\mathrm{T}_{0} / 2$ \\
& $\mathrm{~S}_{5}=\mathrm{T}_{1}+\mathrm{T}_{0} / 2$ & $\mathrm{~S}_{2}=\mathrm{T}_{2}+\mathrm{T}_{0} / 2$ \\
\hline \multicolumn{2}{|l}{}
\end{tabular}

\section{VI.SIMULATION AND RESULTS}

The simulation of three phase inverter fed PMBLDC motor drive with space vector PWM (SVPWM) is as shown in above figure. Here, the $24 \mathrm{~V}$ constant DC source supplies the motor load through voltage source inverter (VSI).

The system proposed consists of outer speed control loop and inner current control loop. The reference speed command is set as 3000rpm. The specifications of motor parameters are summarized in Table 3 .

\section{TABLE III MOTOR PARAMETERS}

\begin{tabular}{|l|l|}
\hline Parameter & Value \\
\hline Input DC voltage & $24 \mathrm{~V}$ \\
\hline $\begin{array}{l}\text { Fundamental } \\
\text { frequency }\end{array}$ & $50 \mathrm{~Hz}$ \\
\hline Switching frequency & $10 \mathrm{KHz}$ \\
\hline Stator Resistance & $0.36 \Omega$ \\
\hline Stator inductance & $0.6 \mathrm{~m} \mathrm{H}$ \\
\hline Torque constant & $0.036 \mathrm{Nm} / \mathrm{A}$ \\
\hline Moment of inertia & $4.6 \mathrm{u} \mathrm{Kg} \cdot \mathrm{m}^{2}$ \\
\hline Pole pairs & 4 \\
\hline
\end{tabular}

B. Results and Discussion

The simulation is done using MATLAB/SIMULINK. The SVPWM based field oriented control of BLDC motor Simulation is as shown in Fig. 5.

The inverter line to line voltage ( $\mathrm{Vab}$ ) output responce is shown in Fig. 6. and Fig. 7. Shows trapezoidal back emf response of BLDC motor. 


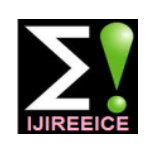

International Journal of Innovative Research in Electrical, Electronics, Instrumentation and Control Engineering

NCAEE 2017

National Conference on Advances in Electrical Engineering NMAM Institute of Technology, Nitte

Vol. 5, Special Issue 2, April 2017

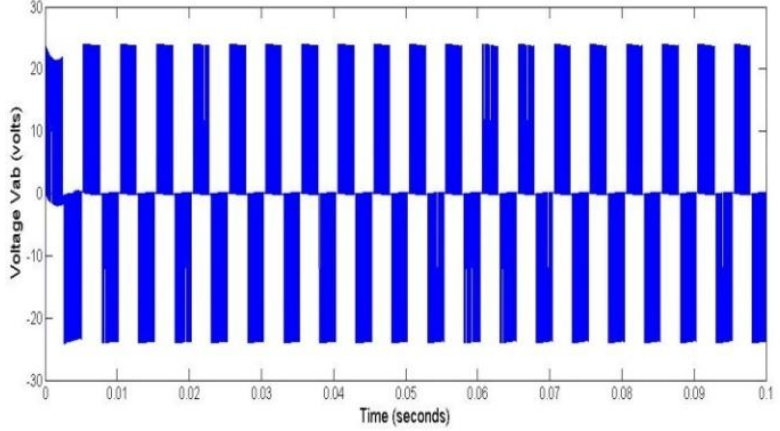

Fig. 6. Inverter line voltage

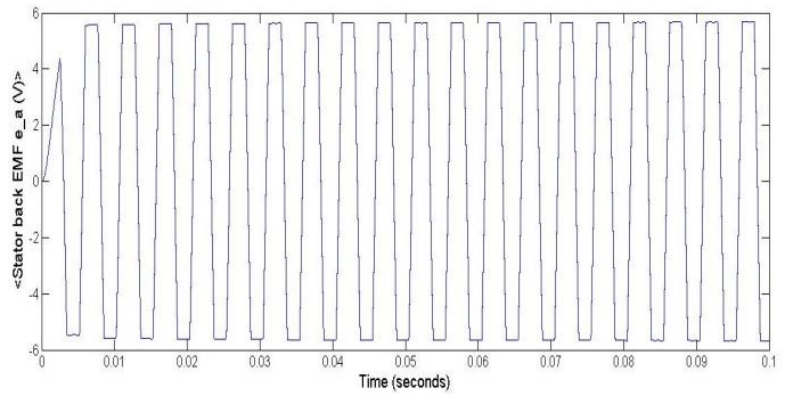

Fig. 7. Trapezoidal back emf response of motor

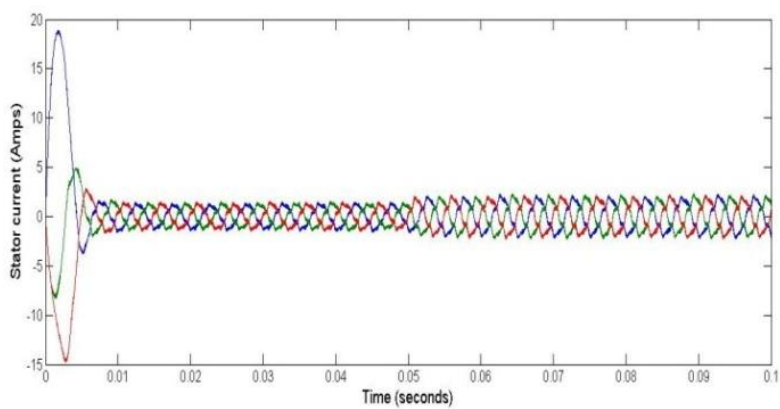

Fig. 8. Three phase stator current

Fig. 8. Shows the three phase motor current. Initially the motor current is high and when it reaches steady state the current will be of 2.3A.

The speed response of BLDC motor is as shown in Fig. 9. From this figure it is observed that the motor speed reaches steady state within $0.06 \mathrm{sec}$.

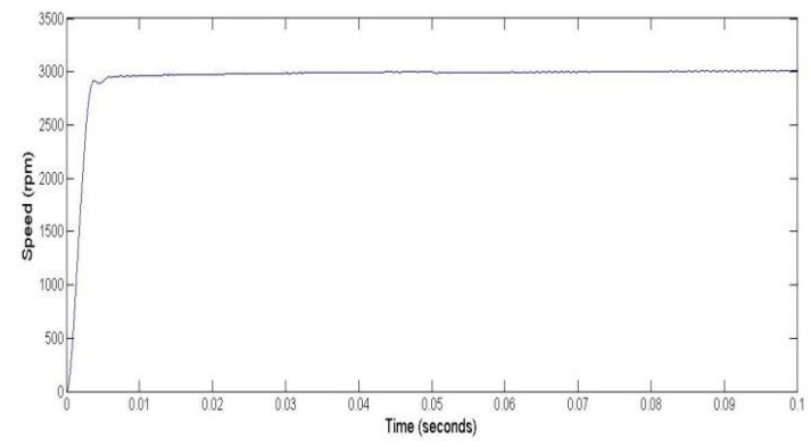

Fig. 9. Motor speed

Fig . 10. shows the electromagnetic torque response of motor. For step change in load torque at $0.05 \mathrm{sec}$ the variation in torque output is shown Fig. 11. From this figure it is observed that the time duration of transient response is very small.

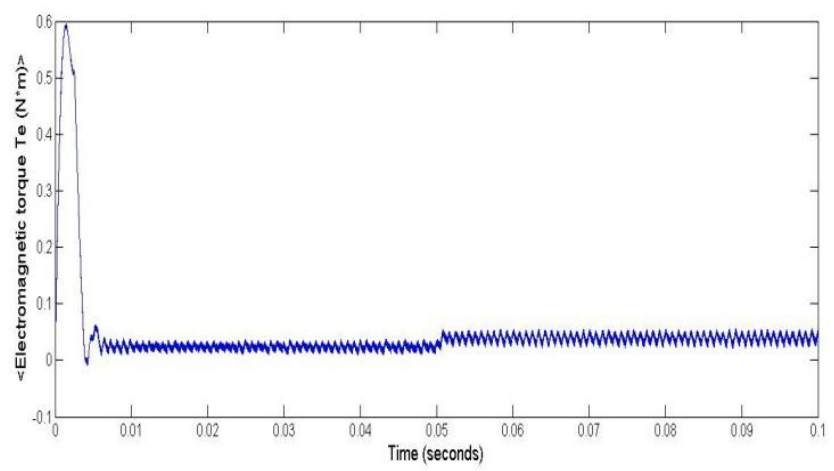

Fig. 10. Electromagnetic torque

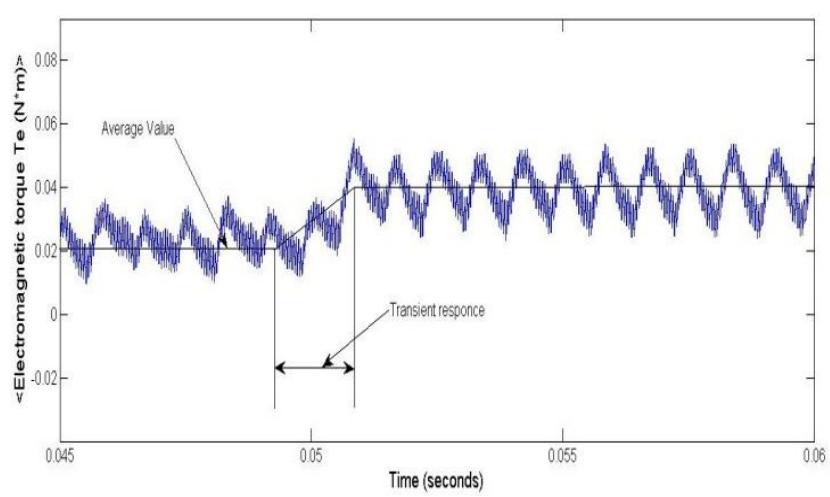

Fig. 11. Electromagnetic torque for change in load torque

\section{CONCLUSION}

In this paper, an indirect field oriented control of Brushless DC motor using Space vector PWM technique has been verified using MATLAB/SIMULINK. From the simulation results, it is observed that the field oriented control technique gives better performance in improving dynamic response of motor and high starting torque with reduced torque ripple while maintaining the other parameters of the system.

\section{ACKNOWLEDGMENT}

Authors gratefully acknowledge the support received from NMAM Institute of Technology, Nitte. Education Trust and VTU, Belagavi in carrying out the research work.

\section{REFERENCES}

[1] Bimal K. Bose, Modern Power Electronics and AC drives, 2008.

[2] “Field oriented control of 3-Phase AC-motors," Texas instrument, 1998. 
National Conference on Advances in Electrical Engineering

NMAM Institute of Technology, Nitte

Vol. 5, Special Issue 2, April 2017

[3] Bhim Singh and Sanjeev Singh, "State of the art on permanent magnet brushless DC motor drives," Journal of Power Electronics, Vol. 9, No. 1, Jan 2009.

[4] Fizatul Aini Patakor, Marizan Sulaiman and Zulkifilie Ibrahim, "Comparison performance of induction motor using svpwm and hysteresis current controller," Journal of Theoretical and Applied Information Technology, Vol. 30 No.1, 2011.

[5] M.Srikanth and Dr. G.V.Siva Krishna Rao, "Modeling, Simulation and Closed Loop Speed Control of BLDC Motor," International Journal of Power System Operation and Energy Management, Vol. 4, 2013.

[6] B. Pavan Kumar and Krishnan C.M.C, "Comparative study of different control algorithms on brushless DC motors," Biennial International Conference on Power and Energy Systems:Towards Sustainable Energy (PESTSE),2016 IEEE

[7] Battu Prakash Reddy and Ashwin Murali, "SoC FPGA-Based Field Oriented Control of BLDC Motor Using Low Resolution Hall Sensor," Industrial Electronics Society, 2016. IECON 42nd Annual Conference of the IEEE.

[8] S.Rambabu, "Modeling and control of a brushless dc motor," M. Eng. thesis, National Institute of Technology, Rourkela, India, 2007. 